\title{
COMMENT
}

\section{WHAT DID THE FRAMERS OF THE FEDERAL CONSTITUTION MEAN BY "AGREEMENTS OR COMPACTS"?}

ABRAHAM C. WEINFELD*

\begin{abstract}
7 HE CONSTITUTION of the United States, Article I, Section Io provides:

No State shall enter into Any Treaty, Alliance or Confederation;

No State shall, without the Consent of Congress, . . . . enter into any Agreement or Compact with another State, or with a foreign Power, . . . .
\end{abstract}

A state may not enter into a treaty but it may enter into an agreement or compact with consent of Congress. What is the difference between a "treaty" and an "agreement or compact"? Is not every treaty an agreement?

Since the Constitution sheds no light on the subject one naturally turns to the proceedings of the federal convention. That convention began its deliberations in Philadelphia in May, $\mathbf{1 7 8 7}$. The period till July 26 was devoted to a general discussion of fundamental issues. Treaties were mentioned in connection with their supremacy over state legislation and in connection with which organs of the federal government should be entrusted with the power to make treaties, but nobody seems to have mentioned "agreements or compacts." On July 25th a Committee of Detail was created and the convention adjourned till August 6th, "that the Come. of Detail might have time to prepare \& report the Constitution." The Committee of Detail consisted of five members: John Rutledge of South Carolina, chairman; James Wilson of Pennsylvania, Edmund Randolph of Virginia, Nathaniel Gorham of Massachusetts, and Oliver Ellsworth of Connecticut. Several of the outlines and drafts prepared by some of those men have been preserved. The first time that the distinction between "treaties" and "agreements or compacts" was introduced appears to have been in connection with a draft of the Constitution in the handwriting of James Wilson. ${ }^{2}$ Section ro of that draft read as follows:

* Senior Attorney, Department of Commerce, Office of National Recovery Administration.

12 Farrand, The Records of the Federal Convention I28 (IgII).

2 Farrand, id., at I69. 
Io. No State shall enter into any Treaty, Alliance or Confederation; nor lay any Imposts or Duties on Imports. .... .

The draft shows emendations in the handwriting of Rutledge, made presumably after discussion with Wilson and other members of the Committee. Those changes made the section read as follows:

Io. No State shall enter into any Treaty, Alliance, Confederation with any foreign

Power nor witht. Const. of U.S. into any agreement, or compact wh another

State or Power; nor lay any Imposts or Duties on Imports; . . . . .

On August 6, 1778 , Rutledge in behalf of the Committee of Detail reported to the Convention and submitted a draft of a Constitution which contained Sections XII and XIII reading as follows: ${ }^{3}$

XII. No State shall coin money; .... nor enter into any treaty, alliance or confederation; .... .

XIII. No State, without the consent of the Legislature of the United States, shall emit bills of credit ....; nor enter into any agreement or compact with another State, or with any foreign power. ...."

The convention continued its deliberations from August 6 till September I7, numerous changes and amendments were made, the "Committee of revision or Stile \& arrangement" was created which included in its membership Madison and Hamilton, the committee went over the document and reported September $12,{ }^{4}$ but nothing appears to have been said or done by anybody about "agreements or compacts," and finally the provision was included in the Constitution as approved by the convention on September I 7 , I787.

In the State conventions called to ratify the federal Constitution there appears to have been no discussion or reference to "agreements or compacts."'5

Samuel Johnson, in his dictionary, ${ }^{6}$ wrote the following:

Agreement ... Compact; bargain; conclusion of controversy; stipulation.

Compact.....A contract; an accord; an agreement; a mutual and settled appointment between two or more, to do or to forbear something.

Treaty......A compact of accommodation relating to public affairs.

That dictionary obviously throws no light on the question.

The Articles of Confederation adopted in 1777 contained the words "agreement" and "treaty":

ARTICLE VI. No State without the consent of the United States in Congress assembled, shall send any embassy to, or receive any embassy from, or enter into any conference, agreement, alliance or treaty with any king, prince or state. ....

3 Farrand, id., at $I 87$.

4 Farrand, id., at 590, note 8 .

$s$ Elliott, Debates on the Federal Constitution ( $1836-45$ ).

${ }^{6}$ A Dictionary of the English Language (2d ed. London 1756). 
No two or more States shall enter into any treaty, confederation or alliance whatever between them, without the consent of the United States in Congress assembled, specifying accurately the purposes for which the same is to be entered into, and how long it shall continue.

No State shall lay any imposts or duties, which may interfere with any stipulations in treaties, entered into by the United States in Congress assembled, with any king, prince or state, in pursuance of any treaties already proposed by Congress, to the courts of France and Spain.....

ART. IX. The United States in Congress assembled, shall have the sole and exclusive right and power of determining on peace and war, except in the cases mentioned in the sixth article- of sending and receiving ambassadors - entering into treaties and alliances, provided that no treaty of commerce shall be made whereby the legislative power of the respective States shall be restrained from imposing such imposts and duties on foreigners, as their own people are subjected to, or from prohibiting the exportation or importation of any species of goods or commodities whatsoever- . . . .

The United States in Congress assembled shall never engage in a war-nor enter into any treaties or alliances .... unless nine States assent to the same. . . .

Though the first paragraph of Article VI mentions both an agreement and a treaty, it contains no clue as to what the difference between them might be. On the contrary, it creates the impression that the word "agreement" was inserted as a catch-all term to include every possible understanding. But a consideration of the various drafts that preceded the final form of the Articles of Confederation and a comparison of the articles with the Constitution show a curious consistency in the use of the word "agreement."

The first elaborate draft of the Articles of Confederation was submitted to the Continental Congress on July 12 th, $177^{67}$ and was soon thereafter printed. It contained the following:

ARTICLE IV. No Colony or Colonies, without the Consent of the United States assembled, shall send any Embassy to or receive any Embassy from, or enter into any Treaty, Convention or Conference with the King or Kingdom of Great-Britain, or any foreign Prince or State. ... .

ART. V. No two or more Colonies shall enter into any Treaty, Confederation or Alliance whatever between them, without the previous and free Consent and Allowance of the United States assembled, specifying accurately the Purposes for which the same is to be entered into, and how long it shall continue.

ART. XV. When the Boundaries of any Colony shall be ascertained by Agreement, or in the Manner hereinafter directed, all the other Colonies shall guarantee to such Colony the full and peaceable Possession of, and the free and entire Jurisdiction in and over the territory included within such Boundaries.

ART. XVIII. The United States assembled shall have the sole and exclusive Right and Power of .... Sending and Receiving Ambassadors under any CharacterEntering into Treaties and Alliances-Settling all Disputes and Differences now sub-

${ }^{7} 5$ Journals of the Continental Congress 547, 549, 550, 555 
sisting, or that hereafter may arise between two or more Colonies concerning Boundaries, Jurisdictions, or any other Cause whatever. - . . . The United States assembled shall never engage the United Colonies in War, .... nor enter into Treaties or Alliances . . . . unless the Delegates of nine Colonies freely assent to the same. . . . .

The second printed draft was considered by the Continental Congress on August 2oth, $1776^{8}$ and contained the following provisions:

ARTICLE IV. No State, without the consent of the United States in Congress Assembled, shall send any Embassy to or receive any embassy from, or enter into any conference, agreement, alliance, or treaty with any King, Prince or State; ....

ART. V. No two or more States shall enter into any treaty, confederation or alliance whatever between them, without the Consent of the United States in Congress Assembled, specifying accurately the purposes for which the same is to be entered into and how long it shall continue.

ART. XIV. The United States Assembled shall have the sole and exclusive right and power of .... sending and receiving Ambassadors-entering into treaties and alliances-deciding all disputes and differences now subsisting, or that hereafter may arise between two or more States concerning boundaries, jurisdictions, or any other cause whatever- . . . The United States in Congress assembled shall never engage in a war, .... nor enter into treaties or alliances except for peace .... unless nine States assent to the same.

Article XV of the first printed draft was omitted in the second printed draft. Subsequently and on November I 5 th, I777, the Continental Congress considered a report which differed slightly from the final form of the Articles of Confederation and then adopted the articles in their final form. ${ }^{9}$

The right to enter into "agreements" was limited only as between a State and a foreign power, consent of Congress being required (Article IV of the second printed draft, Article VI of the final form, Article IV of first printed draft where the word "convention" is used instead of "agreement"). In no draft was the word "agreement" used when limitations were imposed on the right of the colonies or the States to make arrangements among themselves (Article $\mathrm{V}$ of the first and second printed drafts; Article VI of the final form); in other words, "agreements" of the colonies or States among themselves were permitted without any limitation whatever. The fact that the draftsmen of the Articles of Confederation while working on three different drafts in the period of one and one-half years consistently gave the States a limited right to enter into agreements with foreign powers, and gave them an unlimited right to enter into agreements among themselves and the further fact that ten years later, in the Constitution, the rights of the States to enter into agreements among themselves became limited, show that the men of those times used "agreement"

$$
{ }^{8} I d ., \text { at } 675,676,68 I . \quad \quad 99 \text { id., at go7-925. }
$$


as if the word had a distinct and clear meaning for them and not merely as a catch-all term to supplement others.

Apart from the Articles of Confederation and the drafts that preceded them, let us consider the federal convention of 1787 . In that assembly were many good, and some excellent, lawyers. They weighed words with the utmost care for weeks and months. The language which forbade treaties but permitted agreements or compacts with consent of Congress was before those lawyers for six weeks, from August 6th till September I 7 th. Though to us the language suggests no distinction at all, they approved it without any question. The only reasonable explanation of this phenomenon is that the words "agreements or compacts" in contrast to "treaties" were used as technical terms taken from the field of international dealings, that they were words of art, carried a definite meaning and therefore called for no discussion.

To ascertain that meaning one must obviously turn to the literature on international law in existence in 1787 and known in this country at that time. Somewhere among the classifications of treaties and international agreements there may be a classification that will fit the distinction underlying the constitutional provisions in question. Many writers whose works were in existence at that time appear not to have discussed classifications of international agreements and treaties, or, if they did, these classifications can by no stretch of the imagination be used to explain the difference between "treaties" and "agreements or compacts." They are: Giovanni da Legnano, ${ }^{\text {to }}$ Balthazar Ayala, ${ }^{\text {Ix }}$ Alberico Gentili, ${ }^{\text {,2 }}$ Richard Zouche, ${ }^{13}$ Samuel Pufendorf, ${ }^{14}$ Samuel Rachel, ${ }^{15}$ Johann Wolfgang Textor, ${ }^{16}$ Cornelius Van Bynkershoek ${ }^{17}$ and J. J. Burlamaqui. ${ }^{18}$ Hugo Grotius $^{\mathrm{T} 9}$ distinguished federa, treaties, from pactiones aliae, other agree-

so Tractatus de Bello de Represaliis et de Duello ( $\mathrm{I}_{3} 60$ ), published by Carnegie Endowment for International Peace ( $19 \times 7$ ).

Ix De Jure et Officiis Bellicis et Disciplina Militari (158r), edition of Carnegie Endowment (1917).

"De Jure Belli ( 1598$)$, edition of Carnegie Endowment (1933).

${ }^{33}$ Iuris et Iudicii Fecialis, sive, Iuris inter Gentes, et Quastionum de Eodem Explicatio (1650), edition of Carnegie Institution (I9Ir).

1 De Jure Nahurae et Gentium (1672), edition of Carnegie Endowment (1934).

's.De Jure Naturae et Gentium Dissertationes (I676), edition of Carnegie Endowment (I916)

${ }^{16}$ Synopsis Juris Gentium (1680), edition of Carnegie Endowment (Igr6).

${ }^{27}$ Quaestionum Juris Publici Libri duo (1737), edition of Carnegie Endowment (1930).

${ }_{88}$ Principes du droit de la nature et des gens et du droit public général ( $\mathrm{r} 747$ ).

${ }^{9}$ De Jure Belli et Pacis ( 1625 ), edition of Carnegie Endowment (1925), bk. ii, c. xv, xx, xxi $(\mathrm{x}, \mathrm{xi})$. 
ments. Though the terms remind us of the language used in the constitutional provision the definitions given by Grotius could not possibly be relied on by the framers of the constitution because of the remoteness of the subject matter embraced in the definitions. His follower and annotator Jean Barbeyrac ${ }^{20}$ did not change the definitions.

Christian L. B. de Wolff" distinguished between "federa" and "pactiones" and defined them in a way that appears relevant to the constitutional provision but there seems to be no proof that Wolff's work was known in this country in 1787 .

Another author was Emeric de Vattel..$^{22}$ The circumstances under which his work became known in this country are recited by Albert de Lapradelle in his introduction to the edition of Vattel's work published by the Carnegie Endowment for International Peace, at page xxix:

... . From 1758 to 1776 Grotius, Pufendorf, and Burlamaqui were read, studied, and commented upon in the English colonies of America, but Vattel, at that time, seems to have been unknown to them. In I773 the Law of Nations was taught at Kings College (now Columbia University). In 1774 Adams, and in I775 Hamilton, quote or praise Grotius, Pufendorf, Locke; neither mentions Vattel. But the War of Independence gave the United Colonies the new name of States. A hard task engaged the American people, who, by the study of the Law of Nature and of Nations, were preparing themselves for the great work of independence. Anxious to build upon solid foundations, their statesmen turned to European publicists. Charles F. W. Dumas, a Swiss living in Holland, and an ardent republican, re-read Vattel with the United States in mind, brought out a new edition with notes inspired by recent events, and sent three copies of it to Franklin.

The letter by Benjamin Franklin to Dumas acknowledging receipt of those copies read as follows:23

DEAR SIR:

Philadelphia, December I9, 1775

... I I am much obliged by the kind present you have made us of your edition of Vattel. It came to us in good season, when the circumstances of a rising State make it necessary frequently to consult the law of nations. Accordingly, that copy which I kept (after depositing one in our own public library here, and sending the other to the College of Massachusetts Bay, as you directed) has been continually in the hands of the members of our Congress now sitting, who are much pleased with your notes and preface, and have entertained a high and just esteem for their author. ... .

${ }^{20}$ I Grotius, Le Droit de la guerre et de la paix 474 (Amsterdam, I724).

2x Jus Gentium, Methodo Scientifica Pertractatum (1749), edition of Carnegie Endowment (1934), c. iv, $\$ 369$.

${ }^{22}$ Le Droit des gens ou principes de la loi naturelle (1758), edition of Carnegie Endowment (IgI6).

${ }^{23} 2$ Wharton, United States Revolutionary Diplomatic Correspondence 64 (r889). 
With reference to the copy given to the library the following is of interest:

... . This copy [presented by Dumas to the Philadelphia library] undoubtedly was used by the members of the Second Continental Congress, which sat in Philadelphia; by the leading men who directed the policy of the United Colonies until the end of the war; and, later, by the man who sat in the Convention of 1787 and drew up the Constitution of the United States, for the library was located in Carpenters' Hall, where the First Congress deliberated, and within a stone's throw of the Colonial State House of Pennsylvania, where the Second Congress met, and likewise near where the Constitution was framed.24

James Wilson, a member of the Committee of Detail, was familiar with Vattel. He was the author of the draft of the Constitution in which the phrase "agreement or compact" appears for the first time though in the handwriting of Rutledge, chairman of the Committee. In the Pennsylvania convention called to ratify the Federal Constitution, on December 4, $1787^{25}$ Wilson referred to "All the political writers from Grotius and Puffendorf down to Vattel." He must have been well versed in international law. "In 1779 he was commissioned advocate-general for France and in this capacity he represented Louis XVI in all claims arising out of the French alliance until the close of the war." ${ }^{26}$ The chairman of the Committee, John Rutledge, had studied law in England, was a delegate from South Carolina to the Continental Congress for three years, was chief justice of the highest court of South Carolina, I79I-I795, and in the latter year served as Chief Justice of the Supreme Court of the United States during one term. ${ }^{27}$ Oliver Ellsworth, another member of the Committee, had been a delegate to the Continental Congress from Connecticut for six years, a judge of the Supreme Court of Errors of Connecticut, and in I 796 was appointed Chief Justice of the Supreme Court of the United States. ${ }^{28}$ In all likelihood Rutledge and Ellsworth were familiar with Vattel's work in 1787 .

Vattel was referred to in the debates of the South Carolina convention called to ratify the federal Constitution. ${ }^{29}$

Book II, chapter xii of Vattel's work contains the following:

Secrion I52. Treaties of Alliance and other public treaties..... A treaty, in Latin foedus, is a pact entered into by sovereigns for the welfare of the State, either in perpetuity or for a considerable length of time.

${ }^{24}$ Introduction to Vattel's book, edition of Carnegie Endowment, v. iii, p. $x x x$, note I.

${ }_{25} 2$ Elliott, Debates on The Federal Constitution 454 (1836-45).

${ }_{26}^{26}$ Encyclopaedia Britannica 63I (1929).

${ }^{27} 16$ Dictionary of American Biography 258-259 (I93I).

286 Dictionary of American Biography II2-rI4 (I93I).

${ }^{29} 4$ Elliott, Debates on the Federal Constitution 277-8, 310 (1836-45). 
SEc. I 53. Compacts, agreements or conventions. Pacts which have for their object matters of temporary interest are called agreements, conventions, compacts. They are fulfilled by a single act and not by a continuous performance of acts. When the act in question is performed these pacts are executed once for all; whereas treaties are executory in character and the acts called for must continue as long as the treaty exists.

SEc. I92. Treaties executed by an act done once for all. Treaties which do not call for continuous acts, but are fulfilled by a single act, and are thus executed once for all, those treaties, unless indeed we prefer to give them another name, (see Sec. I53), those conventions, those pacts which are executed by an act done once for all and not by successive acts, are, when once carried out, fully and definitely consummated. If valid, they naturally bring about a permanent and irrevocable state of things. . . . .

The original French text is as follows:

$\S$ I52. Des Traités d'Alliance \& autres Traités Publics. ... Un Traité, en Latin Foedus, est un Pacte fait en vue du bien public, par les Puissances supérieures, soit à perpétuité, soit pour un temes considérable.

$\S$ I53. Des pactions, accords, ou conventions. Les Pactes qui ont pour objet des affaires transitoires, s'appellent Accords, Conventions, Pactions. Ils s'accomplissent par un acte unique, et non point par des prestations réitérées. Ces Pactes se consomment, dans leur exécution, une fois pour toutes: Les Traités reçoivent une exécution successive, dont la durée égale celle du Traité.

$\S$ I92. Des Traités accomplis une fois pour toutes et consommés. Les Traités qui ne concernent point des prestations réitérées, mais des actes transitoires, uniques et qui se consomment tout d'un coup; ces Traités, si toutefois on n'aime mieux les appeller d'un autre nom (voyez le $\S$ I53): ces Conventions, ces Pactes, qui s'accomplissent une fois pour toutes, et non par des actes successifs; dès qu'ils ont reçu leur exécution, sont des choses consommées et finies. S'ils sont valides, ils ont de leur nature un effet perpetuel et irrévocable: ...

It is my contention that the "agreement or compact" mentioned in the Constitution is the "agreement, convention, compact" described in secs. I53 and I92 of Vattel, his "accord, convention, paction."

What were the kinds of treaties that loomed large in the minds of the framers? There were treaties of peace, of amity and commerce, consular conventions, treaties of navigation. Under the Articles of Confederation such treaties had been entered into. ${ }^{3 x}$ It was not sensible to leave the door open for States to enter into that kind of treaties. But there were other matters with which not only the framers were familiar but even the man on the street, and they were the boundary disputes. The colonies

${ }^{30}$ The translation is that accompanying the edition of the Carnegie Endowment for International Peace except that the word "pacte" I translate as "pact," "paction" as "compact," whereas in that translation "pacte" is "compact," "paction" is "arrangement." My translation is equally correct and it brings out more clearly the relationship between Vattel's ideas and the language of the constitutional provisions.

${ }^{3 x}$ I Butler, Treaty Making Power of the United States $\$ \S$ r58-160 (1902); Crandall, Treaties, Their Making and Enforcement 28-29 (IgI6). 
and the States were continually engaged in such disputes. Colonies tried to settle many by agreements; so did States. ${ }^{32}$ Such agreements necessarily involved frequent cession of strips of land on one side or the other of the agreed boundary line.

Obviously a way had to be left open for the States to settle such disputes by agreements either among themselves or with a neighboring foreign nation and the framers wanted to permit such agreements with consent of Congress. Enumeration of kinds of treaties forbidden or permitted carries the danger that some other kind of treaty may develop for which there will be no provision. The framers therefore preferred to use generic terms to include the treaties they had in mind and similar ones. They had before them the bible of international law, the book of a recognized authority, Vattel, and he described a category of international arrangements, called "accord, convention, paction," which were fulfilled by a single act and not by a continuous performance of acts; when the act in question was performed, such agreements were executed once for all, ${ }^{33}$ if valid they brought about a permanent and irrevocable state of things. ${ }^{34}$ That category clearly described boundary settlements including cessions or exchanges of land connected with such settlements, and so the framers used the words "agreement or compact." The other treaties, of peace, commerce, etc. they simply called "treaty" just as Vattel did in Section I52. Consequently they prohibited a State from making a treaty but permitted making an agreement or compact with consent of Congress.

Of great corroborative value is the fact that one of the earliest systematic commentators on the Constitution after its ratification, St. George Tucker, who was a contemporary of the men who drafted the Constitution, expressly referred to "Vattel, 296, 297" when discussing "treaties" as distinguished from "agreements or compacts." 35

When the first printed draft of the Articles of Confederation uses the word "convention" (Art. IV) and the second printed draft (Art. IV) and the final form (Art. VI) use the word "agreement," the words mean the

${ }^{32}$ The intercolonial agreements enumerated by Frankfurter and Landis in: The Compact Clause of the Constitution, 34 Yale L. J. 685 (1925), at 730-732 involved fixing of boundary lines; so did three out of the four interstate agreements entered into under the Articles of Confederation and enumerated at $732-734$.

33 Vattel op. cit. supra note $22, \$ 153$.

34 Vattel, op. cit. supra note 22, § 192.

35 I Tucker, Blackstone's Commentaries with Notes of Reference to the Constitution and Laws of the Federal Government of the United States and of the Commonwealth of Virginia, Appendix, p. 309 ( 1803 ). Pages "296, 297" in the English translation of Vattel's book published in Dublin in 1792 contain $\$ 815^{2-1} 5^{6}$. 
same thing, being taken from Vattel's trio "accord, convention, paction." When the first draft (Art. XV) refers to mutual ascertaining of boundaries among colonies the word used is "Agreement."

The question might be raised why matters which "bring about a permanent and irrevocable state of things" 36 are called "affaires transitoires," transitory matters. ${ }^{37}$ When this word is taken literally it certainly does not fit the category. What is permanent is not transitory. Story ${ }^{38}$ took the word literally and therefore rejected the explanation advanced by St. George Tucker, that "agreement or compact" refers to transitory affairs. Story asked:

Why may not a compact or agreement between States be perpetual? If it may not, what shall be its duration? Are not treaties often made for short periods, and upon questions of local interest, and for temporary objects?

The truth is that the agreements described by Vattel in Section I 53 are not transitory at all in the usual sense of the word, and to the extent that the category became established in international law, the permanence of the effects of such agreements is stressed.

Wheaton states: ${ }^{39}$

Kinds of International Treaties. General compacts between nations may be divided into what are called transitory (dispositive or executed) conventions, and treaties properly so termed (sometimes called executory conventions). The first are perpetual in their nature, so that, being once carried into effect, they subsist independent of any change in the sovereignty and form of government of the contracting parties; and although their operation may, in some cases be suspended during war, they revive on the return of peace without any express stipulation. Such are treaties of cession, boundary, or exchange of territory, or perhaps those which create a permanent servitude in favour of one nation within the territory of another. (Vattel, Droit de Gens, liv. II, c. I2, §rg2: Martens Precis, liv. II, c. $2, \S 58)$. The second class includes treaties relating to friendship and alliance, commerce and navigation, social and economic issues, extradition, guarantee etc.

A statement by Strupp is to the same effect: $4^{\circ}$

Häufig ist, namentlich in der älteren Literatur, die Unterscheidung in traités und pactes oder conventions (de Vattel, Droit des gens, II, chap. I2 $§$ I52, I 53, I92; Ch. de Martens, Guide diplomatique II, I S. I27): Wheaton, International Law III, cap. II. Ähnlich in neuerer Zeit Hartmann, Institutionen des praktischen Völkerrechts,

${ }^{36}$ Vattel, op. cit. supra note $22, \mathrm{bk}$. II, § I92.

37 Vattel, op. cit. supra note 22 , bk. II, $\S$ I53.

$3^{8}$ Story, Commentaries on the Constitution of the United States, written about 1833 , $\S$ I 402 (4th ed. I873).

${ }^{39}$ I Wheaton, Elements of International Law 504 (6th ed. 1928).

${ }^{40} 2$ Strupp: Wörterbuch des Völkerrechtes und der Diplomatie 65I (1924). Translation: "Frequent is, especially in the older literature, the division into treaties and pacts or conventions (citations). The former are supposed to result in a continuous performance of acts while the latter are fulfilled by a single act. . . . ." 
S. I4I f.u.a.). Erstere sollen eine dauernde Tätigkeit zur Folge haben, während letztere durch einen einmaligen Akt erfüllt werden. .... .

How then did it come about that Vattel used the word "transitory"? Vattel considered it his task to popularize and expound the teachings of Wolff.4x Among the ways Wolff classified treaties was the following:42

$\S 369$. Foedera quid sint; quid pactiones: Foedus dicitur pactum a summis potestatibus boni publici causa in perpetuum, vel longius saltem tempus inter se initum. Pacta vero, quae praestationes transitorias, seu non iterandas continent, Pactionum nomen retinent.

E. gr. Si duae Gentes de auxiliis in bello sibi invicem praestandis conveniunt; pactum hoc docitur foedus; ast si gens una alteri permittit, ut ob annonae caritatem frumentum in regione sua coemat, pactio erit. Istiusmodi quoque pactio sunt induciae mortuorum sepeliundorum causa post praelium factae.

\section{TRANSLATION ${ }^{43}$}

$\S 369$. What treaties are; what compacts are. A treaty is defined as a stipulation entered into reciprocally by supreme powers for the public good, to last for ever or at least for a considerable time. But stipulations, which contain temporary promises or those not to be repeated, retain the name of compacts.

For example, if two nations reciprocally agree to furnish troops to each other in time of war, this stipulation is called a treaty; but if one nation permits another, on account of the high price of grain, to purchase in its territory, this will be a compact. A compact of that sort, also, is the truce made after a battle for the purpose of burying the dead.

The examples given by Wolff certainly justify his characterizing the subjects of a compact as transitory; burying the dead after a battle, purchasing grain because of temporary scarcity, are activities of a passing character. Wolff also describes them as "non iterandas," that is, such as need not be repeated. This latter characterization may refer to the same two examples, or it may refer to a different category, to-wit: to a category of promises that are fulfilled by a single act like cession of territory, fixing a boundary line, and therefore need not be repeated. Vattel used the word "transitory" but omitted the examples which explained it. At the same time he developed the "non iterandas" part of the definition by specifying that the agreements he discussed were performed by a single act, once for all. It is not important whether he correctly or incorrectly interpreted Wolff. What is important is that to the framers of the Constitution and to the lawyers of those times the category of international agreements called by Vattel "accord, convention, paction" was

${ }_{4 \pi}^{4}$ See the introduction by Albert de Lapradelle to the edition of Vattel's book by the Carnegie Endowment for International Peace (Igr6).

42 Christian L. B. de Wolf, Jus Gentinm, Methodo Scientifica Pertractatum, c. iv, \$ 369 (r749).

43 Accompanies edition of Wolff's Jus Gentium by Carnegie Endowment (1934). 
clearly enough described, it fitted a kind of agreement which they desired the states to be in position to enter into, with consent of Congress, and they consequently adopted the phrase.

Vattel's definition, however, is not the only source which explains the meaning of "agreement or compact." Another source is to be found in the agreements actually entered into between the States under the Articles of Confederation. Though one such agreement referred to nothing but the fixing of the boundary line, ${ }^{44}$ others included a variety of subjects, connected with boundaries. The "agreement" between Pennsylvania and New Jersey dated April $26,1783,45$ in addition to fixing the boundary and title to islands in the Delaware River, regulated rights of fishery and jurisdiction of criminal offenses committed on the river. The "compact" between Maryland and Virginia of March 28, I $785^{46}$ regulated navigation on boundary waters, jurisdiction of criminal offenses committed on a part of those waters, fishing, lighthouses, and the right of the citizens of one State to remove their property from the other without payment of any duty, tax or charge. The "convention" between Georgia and South Carolina, dated April 28, $1787^{47}$ regulated the boundary line, navigation on the Savannah River where it formed the boundary line and confirmed certain grants previously made by the States. It is reasonable to assume that when the framers of the federal Constitution used the words "agreements or compacts" they had in mind not only the agreements or compacts as defined by Vattel but an expansion of the term to include the "agreements" and the "compact" and the "convention" as entered into between various states under the Articles of Confederation. Those matters were a subject of general debate prior to the federal convention, specifically with reference to whether or not they had to be submitted to Congress for its consent. St George Tucker expressly mentions the compact between Virginia and Maryland as an example of the "agreements or compacts" which under the federal Constitution may be entered into with consent of Congress. ${ }^{48}$

To summarize, "agreements or compacts" as intended by the framers of the Constitution included (I) settlements of boundary lines with attending cession or exchange of strips of land, (2) regulation of matters connected with boundaries as for instance regulation of jurisdiction of offenses committed on boundary waters, of fisheries or of navigation.

${ }_{44}$ "Agreement" between Pennsylvania and Virginia, dated August 3r, 1779, to Hening's Va. Stat. I822, pp. 533-535.

45 II Pa. Stat. I782, ch. I035, p. I5I. Supplementary agreement was dated Dec. 2, I785, New Jersey Revised Statutes, title III, ch. 6, p. 43.

${ }^{66}$ I2 Hening's Va. Stat. 1823 , p. 50.

${ }^{47}$ I Cooper's S. C. Stat. 1836 , p. 411.

. $4^{8}$ See note 35 supra. 